\title{
Academic Use of Smart Phone and Correlation of its Addiction with Sleep Disturbances among Medical Students
}

\author{
Javeria Mansoor*1, Sindhu Muneer ${ }^{2}$, Loyala Kanwal ${ }^{2}$ \\ ${ }^{1}$ Department of General Medicine, Liaquat National Hospital and Medical College, Karachi, Pakistan. \\ ${ }^{2}$ Department of Community Medicine, Liaquat National Hospital and Medical College, Karachi, Pakistan.
}

\begin{abstract}
Objective: To assess the positive academic usage of smart phone to determine the correlation of its potential addiction with sleeping disturbances among medical students in Karachi, Pakistan.

Methods: A standard scale based questionnaire was constructed and reviewed by a panel of expert for content reliability and validity. The questionnaire consisted of 3 parts: Part "A" for demographic parameters, Part "B" was designed to evaluate Smart phone addiction and Part "C" for assessment of sleep disturbance. The study was conducted in July 2017 which comprised of medical students of the Liaquat National Hospital \& Medical College, Karachi, Pakistan.
\end{abstract}

\begin{abstract}
Results: A total of 212 students participated in which Males were 31.1\% ( $n=66)$, Females were 68.9\% ( $n=146)$. Out of 212, within which 93.3\% ( $\mathrm{n}=198)$ had Smart Phones, 4.71\% $(\mathrm{n}=10)$ had Mobile phones other than smart phones and $1.88 \%(\mathrm{n}=4)$ did not had mobile phone. Majority of students were found to be using Smart phone for academically beneficial use $86.4 \%$ ( $n=171)$. Among 198 smart phone users $51.5 \%$ $(\mathrm{n}=102)$ were found to be addicted with respect to our scale. A positive significant correlation was found between the scores obtained from the Modified Smart phone addiction scale and Sleep disturbance Scale $(\mathrm{rs}=0.536 ; \mathrm{p}<0.001)$.
\end{abstract}

Conclusion: Despite many beneficial uses of Smart phone in the modern era, students are developing smart-phone addiction which may result in sleep deprivation.

Keywords: Questionnaires, Smart phones, Medical students, Sleep deprivation, Applications, Mobile Phone Addiction, Academic use.

\section{INTRODUCTION}

Smart phones have taken place of a necessity rather than a luxury in daily lives of current generation and among all sectors students are most inclined towards its usage [1]. Mobile phones are spreading tremendously in Pakistan and in students specifically to increase their social communication frequency and expand their opportunities for making social relationships and especially due to the reason that they are cost effective. On the list of top 10 countries, Pakistan ranked 10 th with largest number of mobile phone subscribers. An increase from 300,000 (2001) to 90 million (2008) in Pakistan has been observed [2].

A smart phone is a next-generation, multifunctional cell phone that provides voice communication and text-messaging capabilities and facilitates data processing as well as enhanced wireless connectivity [3]. Smartphone usage has spread in many settings including that of healthcare with numerous potential and realized benefits. Health care professionals are able to download user friendly applications popularly known as apps containing enormous clinical resources with one touch, providing decisional tools to help to learn anytime and anywhere [4].

*Address correspondence to this author at the Department of General Medicine, Liaquat National Hospital and Medical College, Karachi, Pakistan. E-mail: javeriaresearcher@gmail.com
There are e-books and medical education apps free to download on smart phone stores. According to a study, medical students embrace and use electronic resources much more than has been reported among practicing clinicians. The current generation of students are the owners of future are shifting from paper to technological resources [5]. The Internet has become an indispensable tool for communication, academic research, and information.

But according to another research conducted in Pakistan it has been indicated that excessive Internet use can lead to a host of problems including academic, physical, psychological and interpersonal nature [6]. A study among medical students of Jeddah, also reported that mobile phone users had positive correlation with poor academic performance and financial problems [7]. And it's also has potential association with addictive personal habits (smoking and consumption of drugs) [8] and therefore internationally, there is growing concern about the adverse health effects of mobile phone use.

A number of studies have demonstrated sleeping disturbances in medical students but only few demonstrate the relationship of heavy internet use with nocturnal sleeping problems [9]. This study will demonstrate the trends of positive usage of smart phones (that is for improving medical knowledge) among medical students and will also assess the sleeping problems associated with its over-usage or addiction as well. 


\section{MATERIALS AND METHODS}

The Research Committee granted approval for the study on 04-06-2016. This study was cross-sectional, convenience sampling technique was used to gather MBBS students from first year to final year. Forms were distributed after taking consent in Lecture halls and online via emails, using Google forms in Liaquat National Hospital and Medical College, Karachi, Pakistan.

\section{Instrument Development}

The Questionnaire was a modification of pre-existing standard scales. It consisted of 3 parts:

Part "A" consisted of questions designed to gather demographic parameters of the study sample. A total of 8 questions were included with one multiple response question about its usage for academic beneficial purpose.

Part "B" was designed to access smart phone addiction from previously designed scales [10,11]. It was named as Modified Smart phone addiction scale, as to clarify its structure an exploratory factor analysis was performed. Which revealed three factors: Dependence (7 questions), effect on health and academic performance (5 questions) and association with sleeping problems (3 questions). A total of 15 items were retained in the final version of the Items of Modified Smart phone addiction scale, with scores from 15-75 and 5-point Likert type measurement (where $1=$ never $2=$ rarely $3=$ sometimes $4=$ often and $5=$ very often). Items with low factor loading were omitted and the total variance explained was $44.60 \%$. The Cronbach's alpha was 0.857 , which revealed high reliability of these factors.

Part "C" was adapted from insomnia screening scale, both consisted of 5-point Likert type scaling (where $1=$ never $2=$ rarely $3=$ sometimes $4=$ often and $5=$ very often). Total Items of sleep disturbance scale were 9 (due to factor analysis), with score range of 9-45.

For the validation of the questionnaire a pilot study was conducted in June 2017 among 20 medical students. Participants were recruited after approval by the Research Committee of Liaquat National Hospital.

SPSS v21 was used for statistical analysis. Mean and standard deviation was computed for quantitative variables. Frequency and percentage was calculated for qualitative variables. In analyzing the scale about the usage of mobile phone, exploratory factor analysis was used to reduce the items and Cronbach's alpha values were also reported of these factors for reliability analysis. Parametric tests: that is, Student's independent t-test was used to see difference of smart phone addiction between male and female and, one way ANOVA was applied to assess difference of score with respect to academic years of participants, Pearson's Correlation Analysis was used for the correlation between Smart phone addiction scores and sleep disturbance scores. $\mathrm{P} \leq 0.05$ was considered as significant.

\section{RESULTS}

In this study a total of 212 students participated with age ranging from 18-26 years. Rest of the details is depicted in Table 1.

Table 1. Demonstrates the Participants from Each Year of Study.

\begin{tabular}{|l|c|c|c|c|c|c|}
\hline & \multicolumn{5}{|c|}{ Year } & Total \\
\hline & $\mathbf{1}^{\text {st }}$ year & $\mathbf{2}^{\text {nd }}$ year & ${\mathbf{3}^{\text {rd }} \text { year }}^{\text {th }}$ year & Final year & \\
\hline Male & $20(30.3 \%)$ & $12(18.2 \%)$ & $13(19.7 \%)$ & $8(12.1 \%)$ & $13(19.7 \%)$ & $\mathbf{6 6}(\mathbf{3 1 . 1 \% )}$ \\
\hline Female & $37(25.3 \%)$ & $3(121.2 \%)$ & $18(12.3 \%)$ & $26(17.8 \%)$ & $34(23.3 \%)$ & $\mathbf{1 4 6}(\mathbf{6 8 . 9} \%)$ \\
\hline Total & $\mathbf{5 7}(\mathbf{2 6 . 9 \%})$ & $\mathbf{4 3}(\mathbf{2 0 . 3} \%)$ & $\mathbf{3 1}(\mathbf{1 4 . 6 \% )}$ & $\mathbf{3 4}(\mathbf{1 6 . 0} \%)$ & $\mathbf{4 7}(\mathbf{2 2 . 2 \%})$ & $\mathbf{2 1 2}(\mathbf{1 0 0 . 0} \%)$ \\
\hline
\end{tabular}

Within 212 students $93.3 \%(\mathrm{n}=198)$ had Smart Phones, $4.71 \%(\mathrm{n}=10)$ had Mobile phones other than smart phones and $1.88 \%(\mathrm{n}=4)$ did not had mobile phone. Out of 198 smart phone users $49.5 \%(\mathrm{n}=98)$ used Mobile data (SIM Card telecom network) for using internet including $31.6 \%(\mathrm{n}=31)$ Males and $68.4 \%(\mathrm{n}=67)$ Females. Within 198 smart phone users $n=86.4 \%(n=171)$ were found to be using it for academically beneficial purpose. Details are shown in Fig. (1).

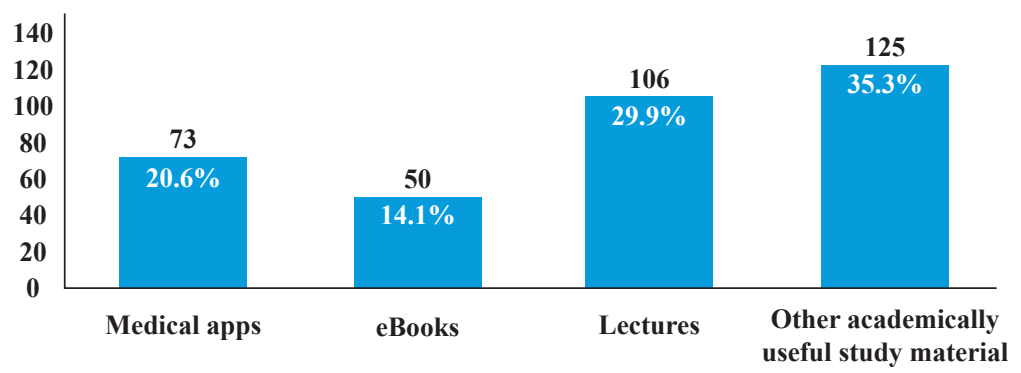

Fig. (1). Graph Demonstrating Number of Subjects Using Mobile Phone for Academic Benefit via Different Means. (Multiple Response Question). 
The responses to smart phone addiction scale with respect to performance and association with sleeping problems are three criteria i.e Dependence, effect on health/academic depicted in Table 2.

Table 2. Items Used for Evaluating Smart Phone Addiction with Frequency and Percentages of Respondents.

\begin{tabular}{|c|c|c|c|c|c|c|}
\hline \multicolumn{2}{|c|}{ Items } & $\begin{array}{l}\text { Never } \\
\text { n(\%) }\end{array}$ & $\begin{array}{l}\text { Rarely } \\
\text { n(\%) }\end{array}$ & $\begin{array}{l}\text { Sometimes } \\
\mathbf{n}(\%)\end{array}$ & $\begin{array}{l}\text { Often } \\
\text { n(\%) }\end{array}$ & $\begin{array}{c}\text { Very } \\
\text { Often } \mathbf{n}(\%)\end{array}$ \\
\hline \multicolumn{7}{|c|}{ Dependence } \\
\hline 1. & Frequency of usage of phone & $0(0)$ & $7(3.5)$ & $28(14.1)$ & $68(34.3)$ & $95(48.0)$ \\
\hline 2. & Feel irritated/anxious when away from phone & $29(14.6)$ & $40(20.2)$ & $57(28.8)$ & $35(17.7)$ & $37(18.7)$ \\
\hline 3 & Feel that life would be empty without phone & $41(20.7)$ & $27(13.6)$ & $62(31.3)$ & $32(16.2)$ & $36(18.2)$ \\
\hline 4 & Have phone in mind when not in use & $61(30.8)$ & $58(29.3)$ & $35(17.7)$ & $29(14.6)$ & $15(7.6)$ \\
\hline 5 & Feel more relieved with phone before going to bed & $22(11.1)$ & $28(14.1)$ & $58(29.3)$ & $59(29.8)$ & $31(15.7)$ \\
\hline 6 & $\begin{array}{l}\text { Use smart phone as a way of relieving a disturbed mood } \\
\text { ( helplessness, guilt, anxiety, stress and depression) }\end{array}$ & $28(14.1)$ & $34(17.2)$ & $68(34.3)$ & $42(21.2)$ & $26(13.1)$ \\
\hline 7. & Have tried again and again to shorten phone use time but failed & $55(27.8)$ & $52(26.3)$ & $31(15.7)$ & $39(19.7)$ & $21(10.6)$ \\
\hline \multicolumn{7}{|c|}{ Effects On Health and Academic Performance } \\
\hline 1. & $\begin{array}{l}\text { Experience lightheadedness or blurred vision due to excessive } \\
\text { use of phone }\end{array}$ & $67(33.8)$ & $59(29.8)$ & $59(29.8)$ & $7(3.5)$ & $6(3.0)$ \\
\hline 2. & Feel pain in wrist or at the back of neck while using phone & $84(42.4)$ & $49(24.7)$ & $33(16.7)$ & $21(10.6)$ & $11(5.6)$ \\
\hline 3. & $\begin{array}{l}\text { Feeling that time on the internet negatively affect academic } \\
\text { performance }\end{array}$ & $46(23.2)$ & $35(17.7)$ & $61(30.8)$ & $29(14.6)$ & $27(13.6)$ \\
\hline 4. & $\begin{array}{l}\text { Having hard time to concentrate in class or while doing } \\
\text { assignments while using phone }\end{array}$ & $41(20.7)$ & $52(26.3)$ & $59(29.8)$ & $23(11.6)$ & 23( 11.6) \\
\hline 5 . & $\begin{array}{l}\text { Avoidance of other activities/neglect studies } \\
\text { in order to stay online }\end{array}$ & $64(32.3)$ & $46(23.2)$ & $57(28.8)$ & 19(9.6) & $12(6.1)$ \\
\hline \multicolumn{7}{|c|}{ Association with Sleep } \\
\hline 1. & Lose sleep due to night time internet use & $58(29.3)$ & $64(32.3)$ & $44(22.2)$ & $20(10.1)$ & $12(6.1)$ \\
\hline 2. & Wake up at night and check phone & $58(29.3)$ & $61(30.8)$ & $29(14.6)$ & $29(14.6)$ & $21(10.6)$ \\
\hline 3. & Check social networking sites right after waking up & $43(21.7)$ & $34(17.2)$ & $46(23.2)$ & $45(22.7)$ & $30(15.2)$ \\
\hline
\end{tabular}

Table 3. Classification of the Participants with Respect to Scores.

\begin{tabular}{|l|c|c|}
\hline Classification & Range of scores & n(\%) \\
\hline Non addicted & less than 30 & $45(22.72)$ \\
\hline Mild addicted & between 31 \& 37 & $51(25.75)$ \\
\hline Moderately addicted & between 38 \& 43 & $49(24.74)$ \\
\hline Severely addicted & between 44 \& 75 & $53(26.76)$ \\
\hline
\end{tabular}

The participants are categorized as Non addicted/Addicted from respective responses, described in detail in Table $\mathbf{3}$. (mild, moderate and severe) according to the scores obtained 
ANOVA test was used to see the significant mean difference of scores of addictions with respect to year of study among medical students. Mean score and their standard deviation was $41.78 \pm 10.16$. We observed no significant mean difference of scores of addictions with respect to year of study $(p=0.316)$. Similarly no difference in mean scores of addiction was found with respect to gender in the smart phone addiction level $(\mathrm{p}=0.397)$.

A positive significant correlation was found between the scores obtained from the Modified Smart phone addiction scale and Sleep disturbance Scale $(\mathrm{rs}=0.536 ; \mathrm{p}<0.001)$ as shown in Fig. (2).

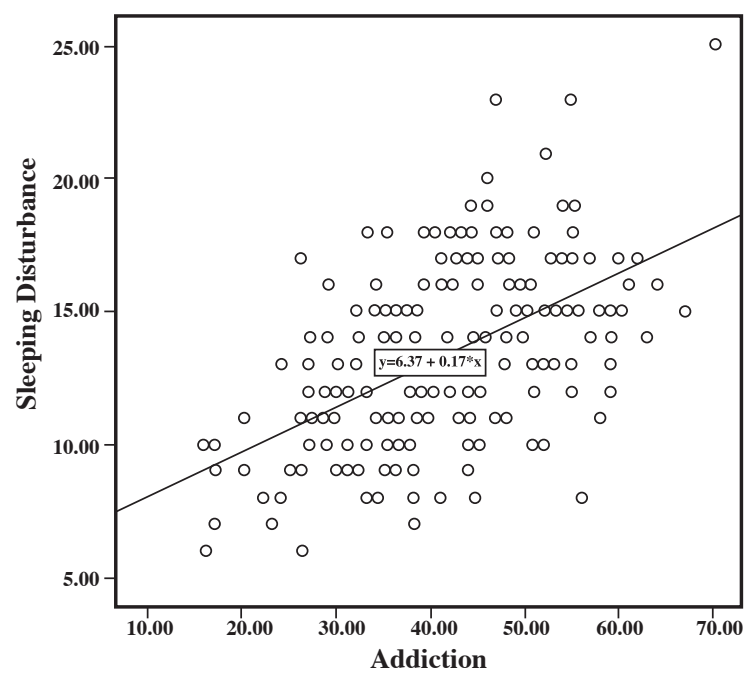

Fig. (2). Correlation between Sleep Disturbance Scale and Modified Smart Phone Addiction Scale.

\section{DISCUSSION}

Over past few years the mobile phone has rapidly become the most widely used technology around the globe [12]. It has replaced not only traditional computers but also traditional media like television and radio. Due to its multi-tasking property it has gained popularity irrespective of culture and race [13]. This fact is revealed in our study in which $93.3 \%$ $(\mathrm{n}=198)$ respondents had smart phone.

In a study conducted in UK, it was stated that use of medical educational apps started in pre-clinical years, [14] this fact is also demonstrated in our study where $20.6 \%(\mathrm{n}=73)$ students were using medical apps out of which $13.63 \%(\mathrm{n}=27)$ were from pre-clinical years (First and second year). In a local study in Islamabad, it was found that $41.46 \%$ of the smart phone users were using medical apps and $28.3 \%$ had relevant text eBooks in their phones, [15] which is comparable to our study where $20.9 \%$ students have medical apps and $14.1 \%$ had eBooks in their smart phones. Although there are now 10,275 unique applications in the Application Store labeled under the "Medical" and "Healthcare and Fitness" categories, [16] this fact is surprising that very few students take benefit from it. Rather, in our study most of the students $35.3 \%$ marked other academically beneficial material, as there are various other means of using smart phone for academic use including educational videos, online tutorials, and many websites in which students can participate in quizzes or multiple choice questions online.

The reason for no difference between the males and female with regard to the smart phone addiction level was explained by a study according to which gender is not a predictor because the appeal of mobile phones with respect to gender is neutral. That is, both males and females have embraced mobile phone technology equally [17]. However, some studies show addiction pattern in favor of females $[18,19]$.

The reason for increasing smart phone addiction besides in people with psychosocial problems is its easy availability and cost-effectiveness as shown by a study, college students are particularly vulnerable to pathological Internet use when access is free and easy; same is the case with smart-phone addiction. According to another study access to the Internet is increasingly easy due to advances in mobile technology and the prevalence of smart-phones, to these days, Social Networking Sites (SNSs) such as Facebook can be easily accessed by not only default internet browsers on smart phones but also some free Smartphone applications. This might be the reason; a number of participants i.e. $49.5 \%$ used mobile data (SIM card) for the use of internet in our study [20, 21].

The question "Do you use the smart phone as a way of relieving a disturbed mood (helplessness, guilt, anxiety, stress and depression)?" was found to be a good predictor in mobile phone dependency criteria, this fact is also demonstrated in a study conducted in India where a similar question was asked and more than two-third of participants gave positive response [22]. In other studies, increased cell phone use was associated with decreased academic performance [23, 24].

\section{CONCLUSION}

The finding that, when mobile phone addiction level increases in the students, the sleep deprivation increase, is in concordance with the results of previous studies including studies conducted in Turkey, Sweden \& Iran. Moreover, a Korean study has also correlated the effect of mobile phone addiction with short duration of sleep. Similar fact was stated by a study that smart phone ownership was related to more electronic media use before sleep, especially calling and messaging and spending time online compared to owners of a conventional mobile phone. As far as local studies are concerned, a study conducted in Lahore has correlated addictive internet use with insomnia and mental health problems, other than that this issue has not been addressed in locally in abundance [25-30]. 


\section{LIMITATIONS}

The limitation of the study was conducted on the students of only one institution.

\section{SOURCE OF FUNDING}

Declared none.

\section{CONFLICT OF INTEREST}

Declared none.

\section{ACKNOWLEDGEMENTS}

We are very grateful to Irfan Zafar (Biostatistian) for his assistance in data analysis, Dr. Saima Zainab and the administration of Liaquat National Hospital and Medical College for granting us permission to circulate questionnaire within the institution.

\section{REFERENCES}

[1] Khattak SJ, Khan B. A novel study to predict trends and policies for mobile communication in multi-environment regions. Wireless Commun Mobile Computing 2018; 2018: Article ID 6397973. DOI: 10.1155/2018/6397973

[2] Ahmed I, Qazi TF. Mobile phone adoption \& consumption patterns of university students in Pakistan. Int J Business Soc Sci 2011 1; 2(9): 205-13.

[3] Zheng P, Lionel MN. Spotlight: The rise of the smart phone. In: IEEE Distributed Systems Online. 2006; 7(3): 3. Available at: $\quad$ https://www.computer.org/csdl/magazine/ds/2006/03/o3003/13rRUyp7u0x.

DOI: $10.1109 / \mathrm{MDSO} .2006 .22$

[4] Payne KF, Wharrad H, Watts K. Smartphone and medical related App use among medical students and junior doctors in the UK. BMC Med Inform Decis Mak 2012; 12: 121.

DOI: $10.1186 / 1472-6947-12-121$

[5] Peterson MW, Rowat J, Kreiter C, Mandel J. Medical students' use of information resources: Is the digital age dawning? Acad Med 2004; 79(1): 89-95.

DOI: 10.1097/00001888-200401000-00019

[6] Suhail K, Bargees Z. Effects of excessive Internet use on undergraduate students in Pakistan. Cyber Psychol Behav 2006; 9(3): 297-307. DOI: 10.1089/cpb.2006.9.297

[7] Ibrahim NK, Baharoon BS, Banjar WF, et al. Mobile phone addiction and its relationship to sleep quality and academic achievement of medical students at king abdulaziz university, Jeddah, Saudi Arabia. J Res Health Sci 2018; 18(3): e00420.

[8] Frangos CC, Frangos CC, Sotiropoulos I. Problematic internet use among Greek university students: An ordinal logistic regression with risk factors of negative psychological beliefs, pornographic sites, and online games. Cyberpsychol Behav Soc Netw 2011; 14(1-2): 51-8. DOI: 10.1089/cyber.2009.0306
[9] Peltzer K, Pengpid S. Nocturnal sleep problems among university students from 26 countries. Sleep Breathing 2015; 19(2): 499-508. DOI: 10.1007/s11325-014-1036-3

[10] Kwon M, Lee JY, Won WY, et al. Development and validation of a smartphone addiction scale (SAS). PloS One 2013; 8(2): e56936. DOI: 10.1371/journal.pone.0056936

[11] Jelenchick LA, Eickhoff J, Christakis DA, et al. The Problematic and Risky Internet Use Screening Scale (PRIUSS) for adolescents and young adults: Scale development and refinement. Comput Human Behav 2014; 35: 171-8.

DOI: $10.1016 /$ j.chb.2014.01.035

[12] Kumar S. Mobile communications: Global trends in the $21^{\text {st }}$ century. Int J Mobile Commun 2004; 2(1): 67-86.

DOI: 10.1504/IJMC.2004.004488

[13] Rice RE, Katz JE. Comparing internet and mobile phone usage: Digital divides of usage, adoption, and dropouts. Telecommun Policy 2003; 27(8): 597-623.

DOI: $10.1016 / \mathrm{S} 0308-5961(03) 00068-5$

[14] Payne KF, Wharrad H, Watts K. Smartphone and medical related App use among medical students and junior doctors in the United Kingdom (UK): A regional survey. BMC Med Inform Decis Mak 2012; 12: 121.

DOI: $10.1186 / 1472-6947-12-121$

[15] Shah J, Haq U, Bashir A, Shah SA. Awareness of academic use of smartphones and medical apps among medical students in a private medical college. JPMA 2016; 66(2): 184-6.

[16] Yadalla HK, Shankar VMR. Professional usage of smart phone applications in medical practice. Int J Health Allied Sci 2012; 1: 44-6. DOI: 10.4103/2278-344X.101656

[17] Bianchi A, Phillips JG. Psychological predictors of problem mobile phone use. Cyber Psychol Behav 2005; 8(1): 39-51. DOI: $10.1089 / \mathrm{cpb} .2005 .8 .39$

[18] Sánchez-Martínez M, Otero A. Factors associated with cell phone use in adolescents in the community of Madrid (Spain). Cyber Psychol Behav 2009; 12(2): 131-7.

DOI: $10.1089 / \mathrm{cpb} .2008 .0164$

[19] Al-Barashdi HS, Bouazza A, Jabur NH. Smartphone addiction among university undergraduates: A literature review. J Sci Res Rep 2015; 4(3): 210-25. DOI: 10.9734/JSRR/2015/12245

[20] Kandell JJ. Internet addiction on campus: The vulnerability of college students. Cyber Psychol Behav 1998; 1(1): 11-7. DOI: $10.1089 / \mathrm{cpb} .1998 .1 .11$

[21] Wu AM, Cheung VI, Ku L, Hung EP. Psychological risk factors of addiction to social networking sites among Chinese smartphone users. J Behav Addict 2013; 2(3): 160-6. DOI: $10.1556 /$ JBA.2.2013.006

[22] Nehra R, Kate N, Grover S, Khehra N, Basu D. Does the 
Excessive use of Mobile Phones in Young Adults Reflect an Emerging Behavioral Addiction?. J Postgrad Med Edu Res 2012; 46(4): 177-82. DOI: 10.5005/jp-journals-10028-1040

[23] Lepp A, Barkley JE, Karpinski AC. The relationship between cell phone use and academic performance in a sample of US college students. SAGE Open 2015; 2015: 1-9

DOI: $10.1177 / 2158244015573169$.

[24] Samaha M, Hawi NS. Relationships among smartphone addiction, stress, academic performance, and satisfaction with life. Comput Hum Behav 2016; 57: 321-5.

DOI: $10.1016 /$ j.chb.2015.12.045

[25] Sahın S, Ozdemir K, Unsal A, Temiz N. Evaluation of mobile phone addiction level and sleep quality in university students. Pak J Med Sci 2013; 29(4): 913-8.

DOI: $10.12669 /$ pjms.294.3686

[26] Thomée S, Härenstam A, Hagberg M. Mobile phone use and stress, sleep disturbances, and symptoms of depression among young adults-a prospective cohort study. BMC Pub Health 2011; 11(1): 1. DOI: 10.1186/1471-2458-11-66
[27] Bayatiani MR, Seif F, Bayati A. The correlation between cell phone use and sleep quality in medical students. Iranian J Med Phys 2016; 13(1): 8-16.

[28] Lemola S, Perkinson-Gloor N, Brand S, Dewald-Kaufmann JF, Grob A. Adolescents' electronic media use at night, sleep disturbance, and depressive symptoms in the smartphone age. J Youth Adolesc 2015; 44(2): 405-18.

DOI: $10.1007 / \mathrm{s} 10964-014-0176-\mathrm{x}$

[29] Lee JE, Jang SI, Ju YJ, Kim W, Lee HJ, Park EC. Relationship between mobile phone addiction and the incidence of poor and short sleep among Korean adolescents: a longitudinal study of the Korean children \& youth panel survey. J Korean Med Sci 2017; 32(7): 1166-72. DOI: 10.3346/jkms.2017.32.7.1166

[30 Zafar N, Kausar R, Pallesen S. Internet addiction, insomnia and mental health problems in university students in Pakistan. Pakistan J Soc Clin Psychol 2018; 16(2): 10-6. 